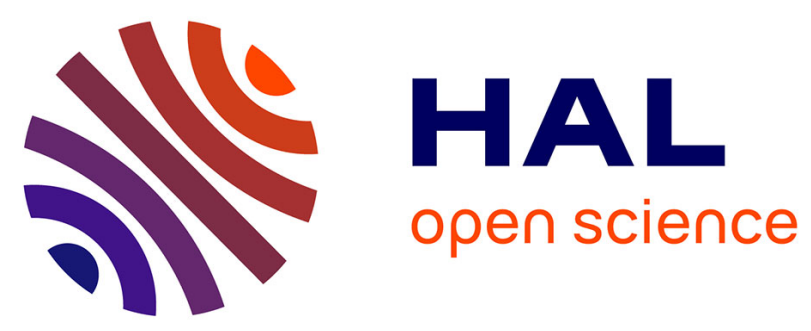

\title{
Relationships between total lightning activity, microphysics and kinematics during the 24 September 2012 HyMeX bow-echo system
}

J.-F Ribaud, Olivier Bousquet, S Coquillat

\section{- To cite this version:}

J.-F Ribaud, Olivier Bousquet, S Coquillat. Relationships between total lightning activity, microphysics and kinematics during the 24 September 2012 HyMeX bow-echo system. Quarterly Journal of the Royal Meteorological Society, 2016, 142, pp.298 - 309. 10.1002/qj.2756 . hal-01386421

\section{HAL Id: hal-01386421 \\ https://hal.univ-reunion.fr/hal-01386421}

Submitted on 24 Oct 2016

HAL is a multi-disciplinary open access archive for the deposit and dissemination of scientific research documents, whether they are published or not. The documents may come from teaching and research institutions in France or abroad, or from public or private research centers.
L'archive ouverte pluridisciplinaire HAL, est destinée au dépôt et à la diffusion de documents scientifiques de niveau recherche, publiés ou non, émanant des établissements d'enseignement et de recherche français ou étrangers, des laboratoires publics ou privés. 


\title{
Relationships between total lightning activity, microphysics and kinematics during the 24 September 2012 HyMeX bow-echo system
}

\author{
J.-F. Ribaud, ${ }^{\mathrm{a} \star}$ O. Bousquet ${ }^{\mathrm{b}}$ and S. Coquillat ${ }^{\mathrm{c}}$ \\ ${ }^{a}$ CNRM-GAME, UMR 3589, Météo-France/CNRS, Toulouse, France \\ b Laboratoire de l'Atmosphère et des Cyclones, UMR 8105, Météo-France/CNRS/Université de La Réunion, St Denis, France \\ ${ }^{\mathrm{c}}$ Laboratoire d'Aérologie, UMR 5560, Université de Toulouse, France
}

${ }^{*}$ Correspondence to: J.-F. Ribaud, CNRM-GAME, 42 Avenue G. Coriolis, 31057 Toulouse Cedex, France.

E-mail: jean-francois.ribaud@aero.obs-mip.fr

\begin{abstract}
The structure of a bow-echo system that crossed southeast France on 24 September 2012 during the first Special Observation Period of the Hydrological cycle in the Mediterranean Experiment (HyMeX) is investigated from a three-dimensional lightning mapping array (LMA), an operational lightning network, and operational polarimetric radar observations. Lightning observations reveal that $97 \%$ of flash initiation and $93 \%$ of flash propagation occurred within the convective region. Through combining LMA and radar-derived microphysical data it is also shown that lightning initiation events and propagation mostly occurred in regions containing graupel (initiation $=70 \%$, propagation $=58 \%$ ), ice (initiation $=22 \%$, propagation $=33 \%$ ), and to a lesser extent hail (initiation $=6 \%$, propagation $=5 \%$ ). The detailed analysis of the lightning activity during two periods of contrasted electrical activity suggests that wet hail growth processes and/or charge redistribution within the cloud may have had a negative impact on lightning initiation occurrences and propagation. The most active periods in terms of lightning activity occurred in conjunction with a vigorous, terrain driven, updraught that transported graupel particles above a height of $12 \mathrm{~km}$.
\end{abstract}

Key Words: dual-polarimetric radar; 3D lightning imager; bow echo

\section{Introduction}

Understanding and forecasting the life cycle of thunderstorms requires a precise understanding of the physical processes at play within these intense weather events. Most studies have investigated these meteorological systems in terms of relationships between dynamical and microphysical signatures. However, electrical effects, which are at the culmination of dynamical cloud and microphysical processes, also provide valuable information about the behaviour and potential impact of these weather systems (e.g. MacGorman and Rust, 1998). Thunderstorm electrification results from a charge separation process that distributes charges of opposite sign at different heights within the cloud (Williams, 1989). It is generally accepted that collisions between ice particles and riming graupel in the presence of supercooled water - a process known as the noninductive mechanism - are involved in charge separation (e.g. Takahashi, 1978; Saunders etal., 1991). To achieve a better understanding of this smallscale process, high space-and-time resolution measurements are required. Thanks to significant progress in lightning and precipitation observation systems that has occurred in the last 20 years, such high-resolution observations are now commonly available to the research community. Hence the advent of efficient lightning detection sensors such as the Lightning Mapping
Array (LMA) in the late 1990s (Rison etal., 1999; Krehbiel etal., 2000) allows documenting the total three-dimensional (3D) structure of lightning, while dual-polarization radars can be used to infer the dominant type of hydrometeor within a given sampling volume (e.g. Marzano etal., 2006; Park et al., 2009).

The potential synergy between LMA and weather radars has already been investigated in past field experiments. For instance Wiens etal. (2005) investigated the complex charge structure of an inverted tripole inside a tornadic supercell from the United States lightning detection network, an LMA and radar observations collected in Kansas during the Severe Thunderstorm Electrification and Precipitation Study (STEPS: Lang et al., 2004). Lang and Rutledge (2008) also used STEPS measurements to document the kinematics and microphysics in relation to electrical aspects of an asymmetric bow-echo system in the High Plains of the central United States. Bruning et al. (2007) highlighted the importance of the noninductive mechanism in global lightning activity using observations within a multicellular storm observed in Oklahoma during the Thunderstorm Electrification and Lightning Experiment (TELEX: MacGorman et al., 2008). More recently, Carey et al. (2015) and Mecikalski et al. (2015) studied several Mesoscale Convective Systems (MCSs) in Alabama to derive total flash rate proxies from radar observables during the 
Deep Convective Clouds and Chemistry (DC3: Barth et al., 2015) experiment.

Most of the aforementioned field campaigns focused on the total lightning structure inferred from very high frequency (VHF)-based lightning mapping systems. Carey et al. (2005) and Dotzek et al. (2005) showed the existence of a lightning pathway throughout two different Leading Line Trailing Stratiform (LLTS) MCSs. Both studies have described the lightning pathway as an electrical connection resulting from charged ice particles ejected from the top of the convective area to the upper part of the radar bright-band region (in the stratiform zone) a few tens of kilometres rearward. Ely et al. (2008) and Hodapp et al. (2008) also showed that the slope of the lightning pathway could evolve in both space and time within other LLTS MCSs. These results have been confirmed by Lang and Rutledge (2008) in their study of an asymmetric bow echo, showing both a downward-sloping upper pathway and a more common constant-altitude lower pathway at mid-troposphere. In addition, Lang and Rutledge (2008) have also highlighted that $99 \%$ of VHF sources retrieved by the LMA were concentrated within or closer than $10 \mathrm{~km}$ to the convective regions within this particular MCS.

Recently, Makowski et al. (2013) have summarized the trend of 30 MCSs that occurred over Oklahoma with particular emphasis on flash rates evolution along with flash initiation zones and cloud-top temperatures. According to this study, flash initiations were concentrated in or near the region of higher reflectivities and colder cloud tops. The characterization of the microphysics associated with lightning initiation events has been addressed by Bruning etal. (2007) and Lund etal. (2009), who studied polarimetric radar signatures within a multicell storm and a small MCS, respectively. The microphysical species having the highest probability of being associated with lightning initiation events was identified as graupel. Lund etal. (2009) also noticed that upper-level lightning initiation (within a normal tripolar charge structure) did arise at the interface between ice and graupel, whereas only graupel seemed to occur for low-level lightning initiation occurrences.

The unique and extensive dataset collected during the first special observing period (SOP1) of the Hydrological Cycle in the Mediterranean Experiment (HyMeX: Drobinski etal., 2014; Ducrocq etal., 2014) offers the possibility to further investigate the complex relationships between cloud microphysics and lightning at play within severe thunderstorms. One of the objectives of HyMeX-SOP1, which took place in autumn 2012 (September-November) in the northern part of the Mediterranean basin, was to better understand the physical processes leading to the development of high-impact weather events in this flood-prone area (e.g. Delrieu et al., 2005; Ducrocq etal., 2008). To achieve the project's goal, several lightning sensors, including an LMA, were deployed in southeastern France (Defer et al., 2015) together with an ambitious radar deployment (Bousquet et al., 2015).

The present study aims at combining LMA and polarimetric radar observations to infer relationships between the total lightning activity, microphysics and kinematics within an intense bow-echo system observed above the complex terrain of southern France during the Intense Observation Period (IOP) 6 of HyMeX. The lightning and radar measurements used in this study are described in section 2, while section 3 provides a brief overview of the meteorological system along with global lightning and microphysical signatures and relationships. Two distinct periods in terms of lightning activity are discussed in section 4 . Conclusions and future research directions are given in section 5 .

\section{Data and methodology}

Observations used in this study consist of three-dimensional fields of lightning, reflectivity, wind and hydrometeor observations deduced from the analysis of LMA, EUropean Cooperation for LIghtning Detection (EUCLID) and operational radar data collected during SOP-1. In order to combine radar and lightning observations, a common Cartesian domain of $200 \mathrm{~km} \times 200 \mathrm{~km} \times 14 \mathrm{~km}$ was constructed with a horizontal grid resolution of $1 \mathrm{~km} \times 1 \mathrm{~km} \times 0.5 \mathrm{~km}$ (Figure 1). Since the sampling of the atmosphere over the whole volume is not instantaneous, it is implicitly assumed that sampled weather systems remain stationary within the time period required by ground-based radars to perform their volumetric exploration. The displacement of observed weather systems during this period is taken into account by spatially advecting (synchronizing) radar data with respect to the middle of each considered volume scan. To account for the differences in temporal resolution between lightning and ground-based radar observations, we only consider lightning data collected within a 5 min period centred on the mid-time of each volume scan.

\subsection{Radar-derived wind and hydrometeor fields}

Three-dimensional wind and reflectivity data are derived from the application of the operational version of the MUltiple-Doppler Synthesis and Continuity Adjustment Technique (MUSCAT), initially proposed by Bousquet and Chong (1998). During HyMeX, this method was applied to the six ARAMIS (Application Radar à la Météorologie Infra-Synoptique) operational radars (Nimes, Montclar, Collobrières, Bollène, Opoul, Sembadel) covering the Cévennes-Vivarais area, allowing the retrieval of multiple-Doppler wind and reflectivity data at the space and time resolution of $1 \mathrm{~km}^{2}$ and $15 \mathrm{~min}$, respectively - the reader is referred to Bousquet and Tabary (2014) and Bousquet et al. (2008) regarding the application of MUSCAT in an operational framework. Uncertainties in wind retrieval resulting from both geometrical issues and long ( $15 \mathrm{~min}$ ) sampling durations inherent in the characteristics of the French radar network were estimated by Bousquet etal. (2008) using synthetic data. It was found that errors in horizontal and vertical wind components were minimum between altitudes of 2 and $10 \mathrm{~km}$, and maximum close to the ground and above $10 \mathrm{~km}$ (maximum errors of $\pm 2 \mathrm{~m} \cdot \mathrm{s}^{-1}$ for horizontal winds and $\pm 1 \mathrm{~m} \cdot \mathrm{s}^{-1}$ for vertical winds). These figures were confirmed through qualitative and statistical intercomparisons of $3 \mathrm{D}$ wind observations inferred from the analysis of $\sim 10 \mathrm{~h}$ of ground-based and airborne radar measurements collected during HyMeX (Bousquet et al., 2016).

Three-dimensional hydrometeor fields are derived from the analysis of Montclar (C-band) and Nimes (S-band) dualpolarization radar observations (Figure 1). Dual-polarimetric radar data are processed according to the procedures described in Figueras i Ventura etal. (2012) and Ribaud etal. (2016). The pre-processing consists in the six steps described hereafter: (i) correction for potential differential reflectivity $\left(Z_{\mathrm{DR}}\right)$ miscalibration following the approaches of Illingworth and Blackman (2002) and Gourley et al. (2006); (ii) discrimination between meteorological and non-meteorological echoes (Gourley et al., 2007); (iii) estimation of the $0{ }^{\circ} \mathrm{C}$ isotherm altitude from polarimetric data (Giangrande etal., 2008) and operational model analyses (here located at $\sim 3.5 \mathrm{~km}$ above mean sea level (AMSL) for the present case-study); (iv) estimation of the specific differential phase $\left(K_{\mathrm{DP}}\right)$; $(\mathrm{v})$ correction of signal attenuation following the approach of Tabary et al. (2009); (vi) application of thresholds on signal-to-noise ratio $(15 \mathrm{~dB})$ and partial beam blockage (10\%).

Once pre-processed dual-polarimetric radar observables (horizontal reflectivity $\left(Z_{\mathrm{H}}\right)$, and differential $\left(Z_{\mathrm{DR}}\right)$ reflectivity, differential phase $\left(\Phi_{\mathrm{DP}}\right)$ and coefficient correlation $\left.\left(\rho_{\mathrm{HV}}\right)\right)$ are ingested into a modified version of the fuzzy logic, hydrometeor classification algorithm initially proposed by Al-Sakka etal. (2013), this new version of the algorithm (Ribaud et al., 2015) improves hydrometeor classification through discriminating between stratiform and convective precipitation and now allows for graupel identification. Hydrometeor fields are retrieved for each radar at the temporal resolution of $15 \mathrm{~min}$ before being 


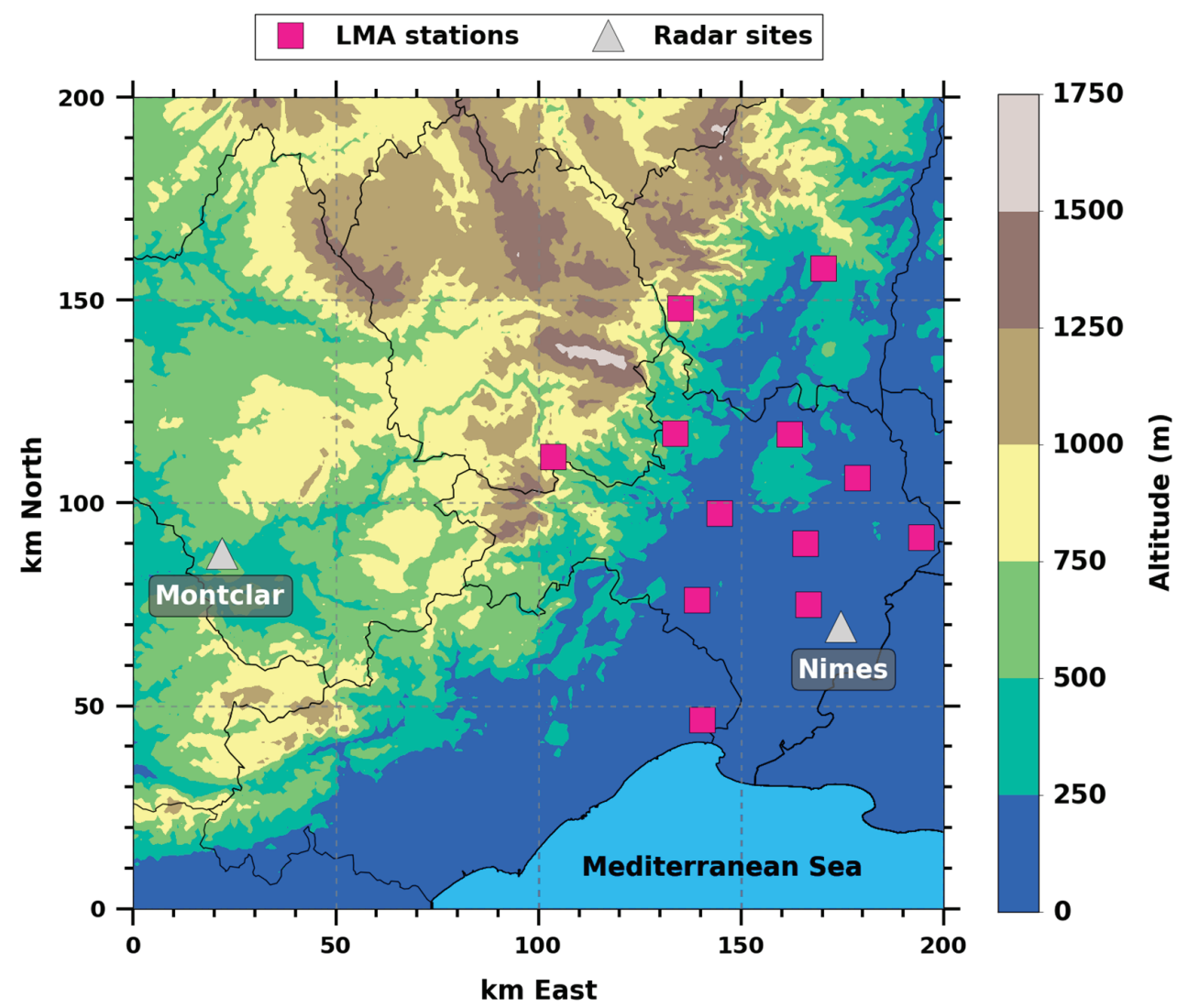

Figure 1. Overview of the $200 \mathrm{~km} \times 200 \mathrm{~km}$ domain of analysis along with topography (colour-shaded). Triangles indicate the location of Montclar and Nimes polarimetric radars. Squares show the location of the 12 LMA stations.

aggregated to produce a two-radar composite over the domain of analysis shown in Figure 1.

\subsection{Lightning data}

The HyMeX Lightning Mapping Array (HyLMA) is composed of 12 stations spread across the Cévennes-Vivarais region (Defer et al., 2015). This instrument allows for locating the sources of VHF radiation from lightning discharges in the three spatial dimensions and every $80 \mu$ s (Rison et al., 1999; Krehbiel et al., 2000 ). The evaluation of the LMA performance was conducted by Thomas etal. (2004) using the New Mexico Tech LMA as well as radiosoundings, aircraft tracks, and simple geometric models. According to the authors, the uncertainties in spatial and temporal localization of lightning sources are in the order of $30 \mathrm{~m}$ and $50 \mathrm{~ns}$, respectively. VHF sources detected by the HyLMA are grouped into flashes using the methodology of Thomas et al. (2003) with a minimum of ten sources required to reconstruct a flash. To mitigate errors in both space and time location of VHF discharges, we used thresholds for both the goodness-of-fit values $\left(\chi^{2}<1\right)$ and the number of stations used within the timeof-arrival method $(\geq 7)$. These typical threshold values allow for an improvement of data quality while keeping enough data for statistical analysis.

The LMA also permits one to distinguish between different parts of a lightning flash. Since the initial VHF source detected by the LMA is close to the actual lightning initiation location, one considers that the first VHF source of a flash corresponds to the lightning initiation locations, whereas other subsequent VHF sources are associated with lightning propagation.

Data collected by the EUCLID network were also used to complement HyLMA observations over the domain of interest. In this area, the EUCLID network allows detection of cloudto-ground (CG) strike locations with an efficiency up to $80 \%$ (Schulz etal., 2014). As a lightning flash could be the sum of several strokes, an algorithm based on both space $(\Delta x=10 \mathrm{~km})$ and time $(\Delta t=0.5 \mathrm{~s})$ criteria was used to gather these events into individual flashes (S. Pedeboy, 2014; personal communication).

\section{IOP 6 case-study}

\subsection{System overview}

During the night of Sunday 23 to Monday 24 September, an intense bow-echo (BE) squall line propagating eastward at a speed of $\sim 14 \mathrm{~m} \cdot \mathrm{s}^{-1}$ passed over the LMA and HyMeX radar network. This system produced rainfall accumulation locally up to $100 \mathrm{~mm}$ in a few hours over the Cévennes-Vivarais region. Bow-echo systems are considered as the most powerful squall lines existing on Earth. These high impact MCSs, whose name comes from the distinctive bow-shape pattern of their leading edge in radar reflectivity images, have been first described by Fujita (1978). Although most BE studies have been focused on systems developing in the region of the Great Plains, the occurrence of these storms is nevertheless not limited to the central United States. Hence a few references to severe BEs that developed outside the continental United States can be found in the literature. For instance, Aran et al. (2009) investigated the synoptic and mesoscale conditions associated with the formation of a tornadic BE in northern Spain; Bousquet et al. (2008) studied the dynamics of a BE that formed near Paris, France, while Meng and Zhang (2012) also investigated a similar system in southern China from a numerical perspective. To the best of our knowledge, the BE observed during HyMeX IOP 6 is however the first event of this kind ever sampled over a region of complex terrain.

The evolution of this MCS between 0000 and 0500 UTC is shown in Figure 2, which presents horizontal cross-sections of composite reflectivity data at $1.5 \mathrm{~km}$ AMSL. This intense squall line developed over the Cévennes-Vivarais region in response to a well-established moist southerly low-level flow (Figure 2(a) and (b)). The MCS reached its mature stage between 0200 and 0300 UTC and progressively developed a pronounced comma-shaped 
(a) 0000 UTC

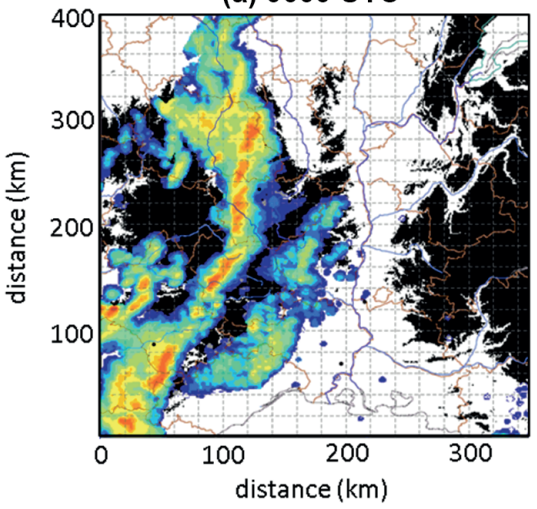

(d) 0300 UTC

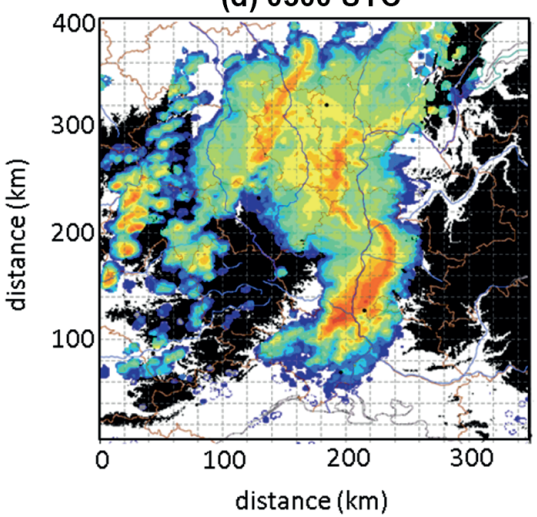

(b) 0100 UTC

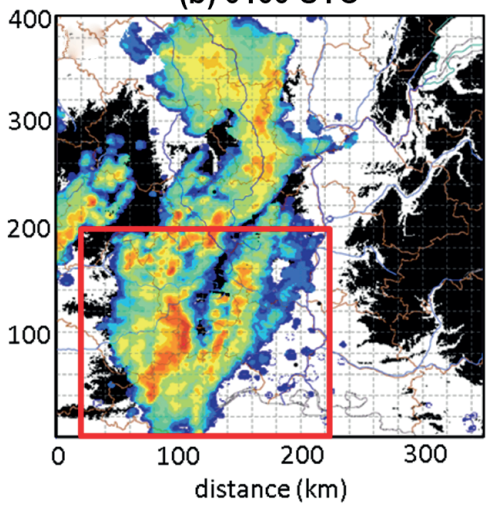

(e) 0400 UTC

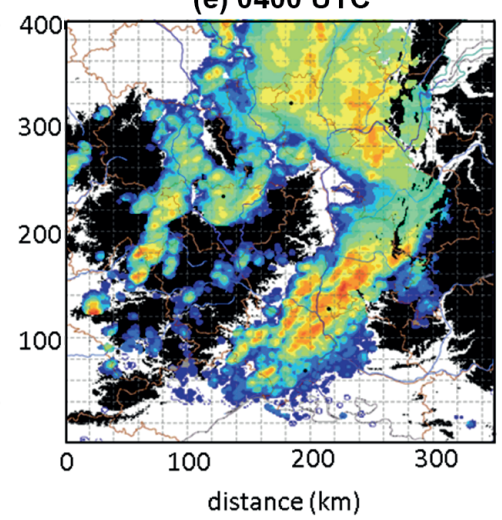

(c) 0200 UTC

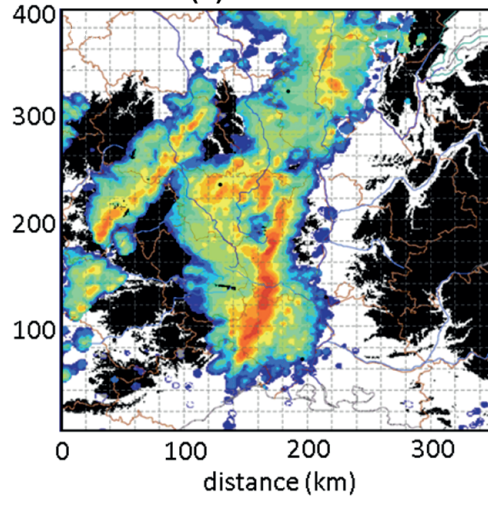

(f) 0500 UTC

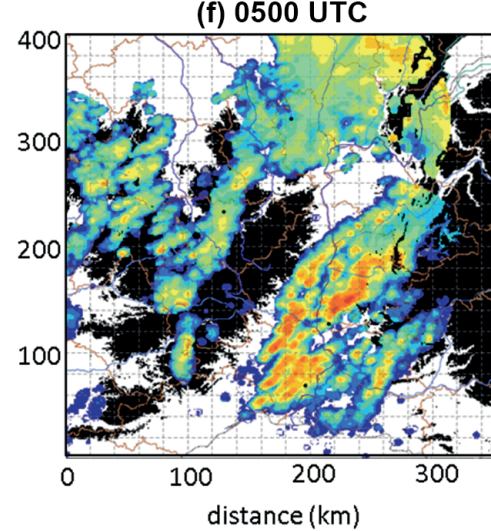

$\mathrm{dBZ}$ 60 50 40 30 20 10

Figure 2. (a-f) Reflectivity composite from multiple radars analysis (dBZ, colour scale to the right) at $1.5 \mathrm{~km}$ AMSL valid from 0000 to 0500 UTC on 24 September 2012. In (b) the red box corresponds to the domain of analysis shown in Figure 1.

echo in the reflectivity imagery (Figure 2(c) and (d)). The system then broke up into two MCSs around 0400 UTC (Figure 2(e)) as a result of the intensification of the front-to-rear inflow in the bow region. While the northernmost system rapidly collapsed (Figure 2(e) and (f)), the second system continued to slowly propagate eastward and produced significant precipitation over southeastern France before reaching northeastern Italy in the morning of 24 September (Ducrocq et al., 2013).

In the following section we will focus on the $4 \mathrm{~h}$ period extending from 2330 UTC 23 September to 0330 UTC 24 September, during which the system was located over the domain of analysis shown in Figure 1.

\subsection{Global lightning activity}

General lightning characteristics during the period of interest (2330-0330 UTC on 23-24 September) are presented in Figure 3 The comparison between the total flash rates (Figure $3(\mathrm{~b})$, black shading) observed by the LMA and flash rates occurring solely within the LMA/radar common domain of analysis (grey shading) shows that most lightning activity occurred within the $200 \mathrm{~km} \times 200 \mathrm{~km}$ domain shown in Figure 1. Within this domain a total of 10272 flashes were detected by the HyLMA. Among these, only $15 \%$ and $3 \%$ were associated with negative and positive CG from the EUCLID network, respectively. Overall, the lightning activity can be divided into three distinct periods. The first period (P1) extends from 2330 to 0130 UTC. It is characterized by a flash rate maximum of up to $160 \mathrm{~min}^{-1}$ at $\sim 0040$ UTC and CG flash rates fluctuating between 15 and $25 \mathrm{~min}^{-1}$ (Figure $3(\mathrm{~b})$ ). The first lightning sources are mainly triggered around the height of $8 \mathrm{~km}$, which corresponds to the limit between two high VHF source density layers (Figure 3(a)). The duration of the second period (P2) is rather short ( $\sim 45 \mathrm{~min})$. It is characterised by significantly weaker electrical activity as indicated by the observed total and CG flash rates of $\sim 40$ and $\sim 10 \mathrm{~min}^{-1}$, respectively. During this phase both the mean altitude of high VHF source density and height of lightning initiation events $(\sim 6 \mathrm{~km}$, Figure $3(\mathrm{a}))$ significantly decreased. The last period (P3) was associated with a lightning 'bloom' that occurred in response to a convective surge between 0220 and 0300 UTC. The height of lightning initiation occurrences sharply increased to $11 \mathrm{~km}$ AMSL, which is consistent with the maximum of VHF source density observed at this level (Figure 3(a)). By contrast, the number of CG detected by EUCLID decreased from $10 \mathrm{~min}^{-1}$ to zero, indicating a significant increase of intra-clouds (IC) lightning proportions (Figure 3(b)). Note that the electrical VHF distribution during the $4 \mathrm{~h}$ analysis period was consistent with that of a normal tripolar charge structure, that is, a main negative charge concentrated around $6 \mathrm{~km}$, surrounded by a weak low-level positive charge at $\sim 3.5 \mathrm{~km}$ height and a main upper-level positive charge at an altitude of $\sim 10 \mathrm{~km}$ (not shown).

In order to characterize more precisely lightning activity during this period, time-height plots of VHF source distributions within both the stratiform and convective areas of the systems are shown in Figure 4. The first observed source of each flash is also shown, to investigate the properties of lightning initiation events. Overall $97 \%$ of first VHF sources detected by the HyLMA occurred in the convective region. During the first period, flashes were distributed between 4 and $12 \mathrm{~km}$ but were mainly triggered near the altitude of $10 \mathrm{~km}$ AMSL. The maximum density of first VHF sources was observed within the 4-6 km layer between 0030 and 0130 UTC. This period coincides well with the increase in the number of CG detected by EUCLID (Figures 3(b) and 4(e)). The convective surge that occurred during the third period is associated with an increase of the lightning triggering altitude. The maximum source density was observed near $11 \mathrm{~km}$ between 0245 and 0300 UTC. During this period one can notice the lack of first VHF sources at low altitude, which is consistent with CG activity (Figures 3(b) and 4(e)).

The VHF sources distribution exhibits a strong imbalance between the convective and stratiform regions. Indeed $93.8 \%$ of the LMA sources were observed within the convective region. If one only considers the first VHF sources, the proportion is even higher $(97.0 \%)$, meaning that lightning was almost exclusively triggered within the convective region. This result is consistent with a study of Lang and Rutledge (2008), showing that 99\% 


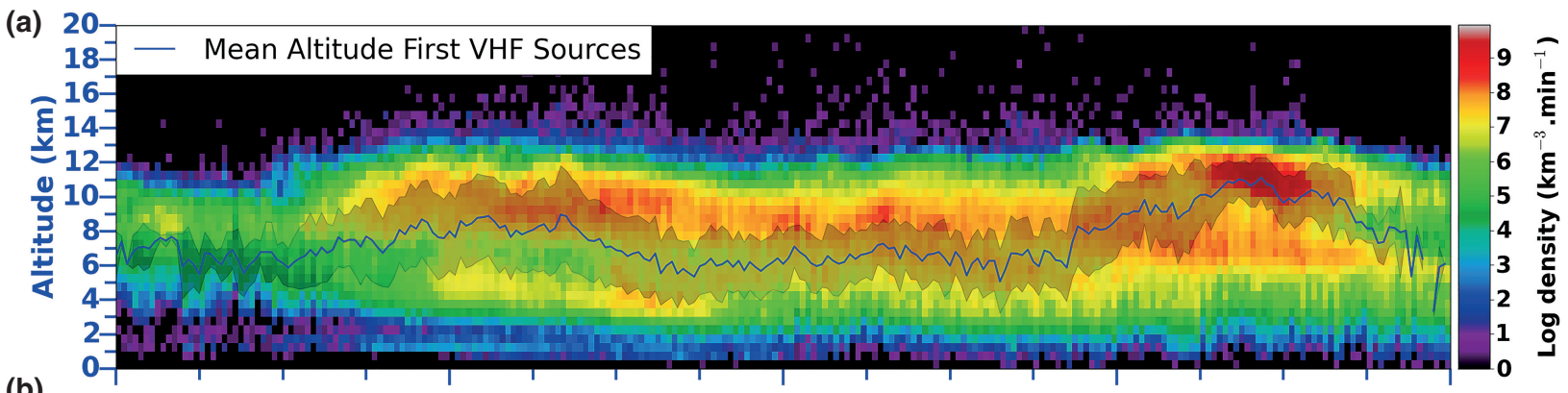

(b)

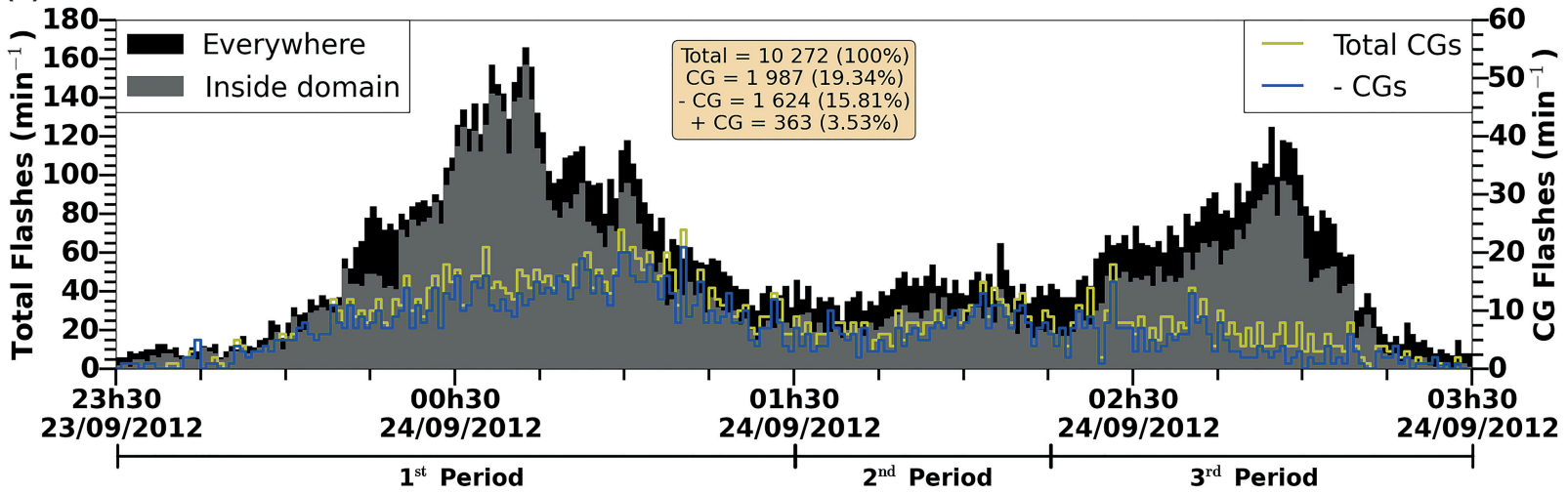

Figure 3. Lightning activity inferred from LMA and EUCLID data over a $4 \mathrm{~h}$ period starting on 23 September 2012 at 2330 UTC. (a) Time-height plot of VHF source density $\left(\mathrm{km}^{-3} \cdot \mathrm{min}^{-1}\right)$. (b) Lightning flash rates. In (a) the blue line and semi-transparent envelope shows the mean and standard deviation of the first VHF source altitude computed every minute. In (b) black shaded areas represent the total flash rate measured everywhere by the LMA, whereas grey shaded areas corresponds to the total flash rate inside the domain of analysis. The yellow (resp. blue) line indicates the total CG rate, including both positive and negative CG flashes (resp. negative CG rate) measured with EUCLID. The beginning and end of the three distinct periods of lightning activity are also indicated.

(a)

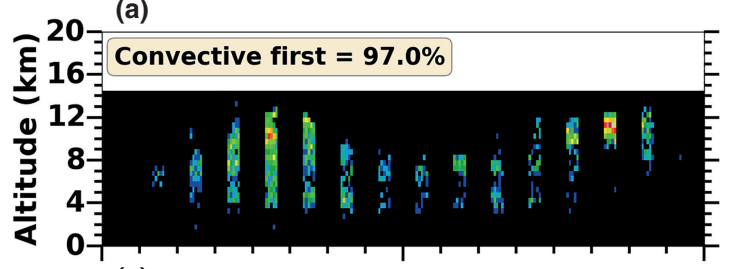

(c)

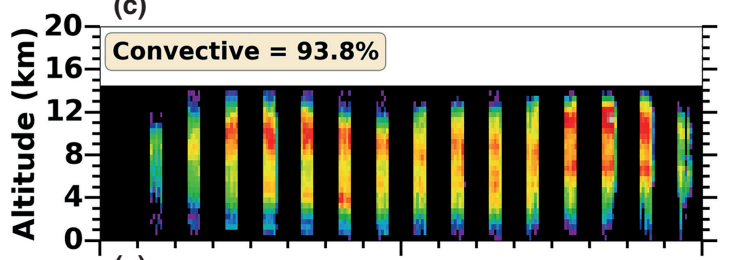

(e)
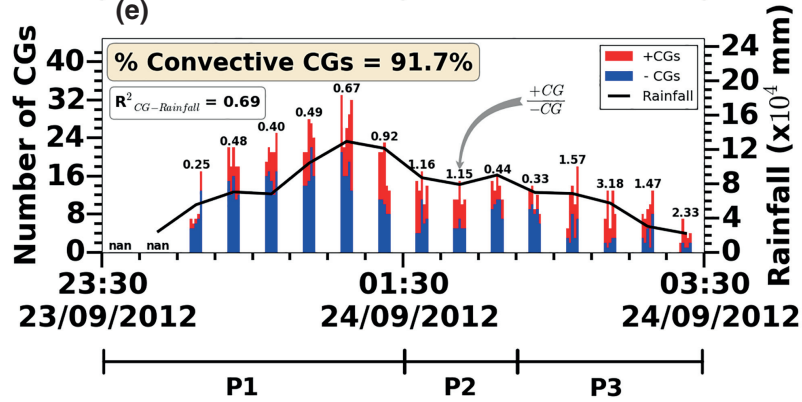

(b)

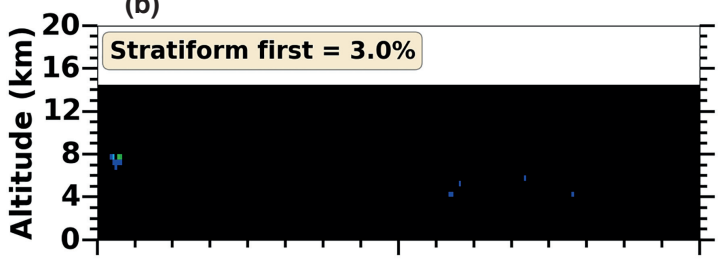

(d)
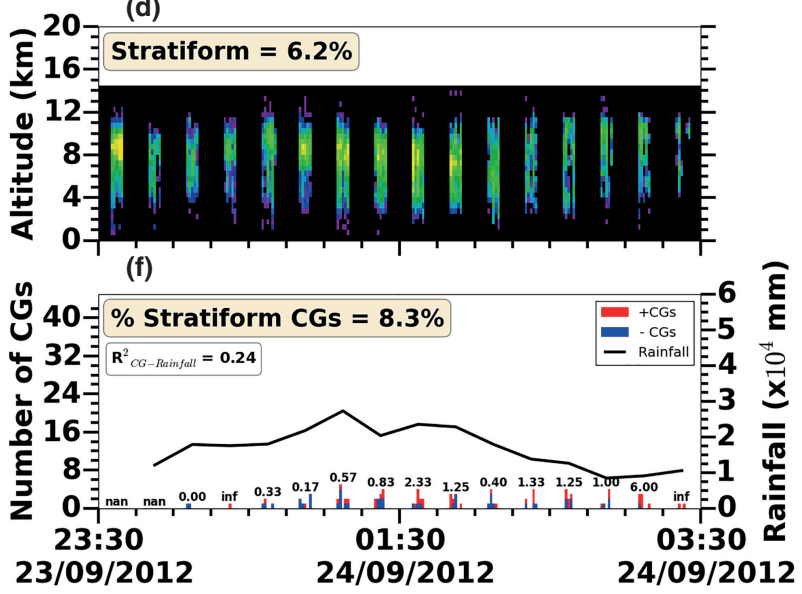

$23 / 09 / 2012 \quad 24 / 09 / 2012$

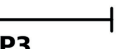

Figure 4. Time-height plots of VHF source density detected by the LMA in (a,c) convective and (b,d) stratiform regions of the squall line by steps of 15 min. Top panels $(\mathrm{a}, \mathrm{b})$ correspond to the first detected VHF source per flash while middle panels $(\mathrm{c}, \mathrm{d})$ corresponds to all sources. Bottom panels (e,f) represent proportions of $+\mathrm{CG}$ and -CG detected by EUCLID in (e) convective and (f) stratiform areas (scale on left). The black line shows cumulated rainfall derived from the analysis of operational quantitative precipitation estimate (QPE) data (scale on right).

of VHF sources were detected within convective areas. This distribution was also observed during period P3 (Figure 4(c) and (d)). By contrast, data collected during period P2 show increased VHF activity in the stratiform region and reduced activity in the convective part of the system. The CG detected by EUCLID mostly occurred within the convective part of the system (Figure 4(e) and (f)). One can also note that the $5 \mathrm{~min}$ positive-negative CG ratio tends to increase (resp. decrease) during P1 and P3 (resp. P2). The intensity of rainfall deduced from operational quantitative precipitation estimation was also maximum in the convective region of the squall line.

3.3. Impact of microphysics on lightning initiation events and propagation

The impact of microphysical species on lightning initiation events and propagation was investigated through combining LMA data and 3D hydrometeor composites. All VHF sources composing a 


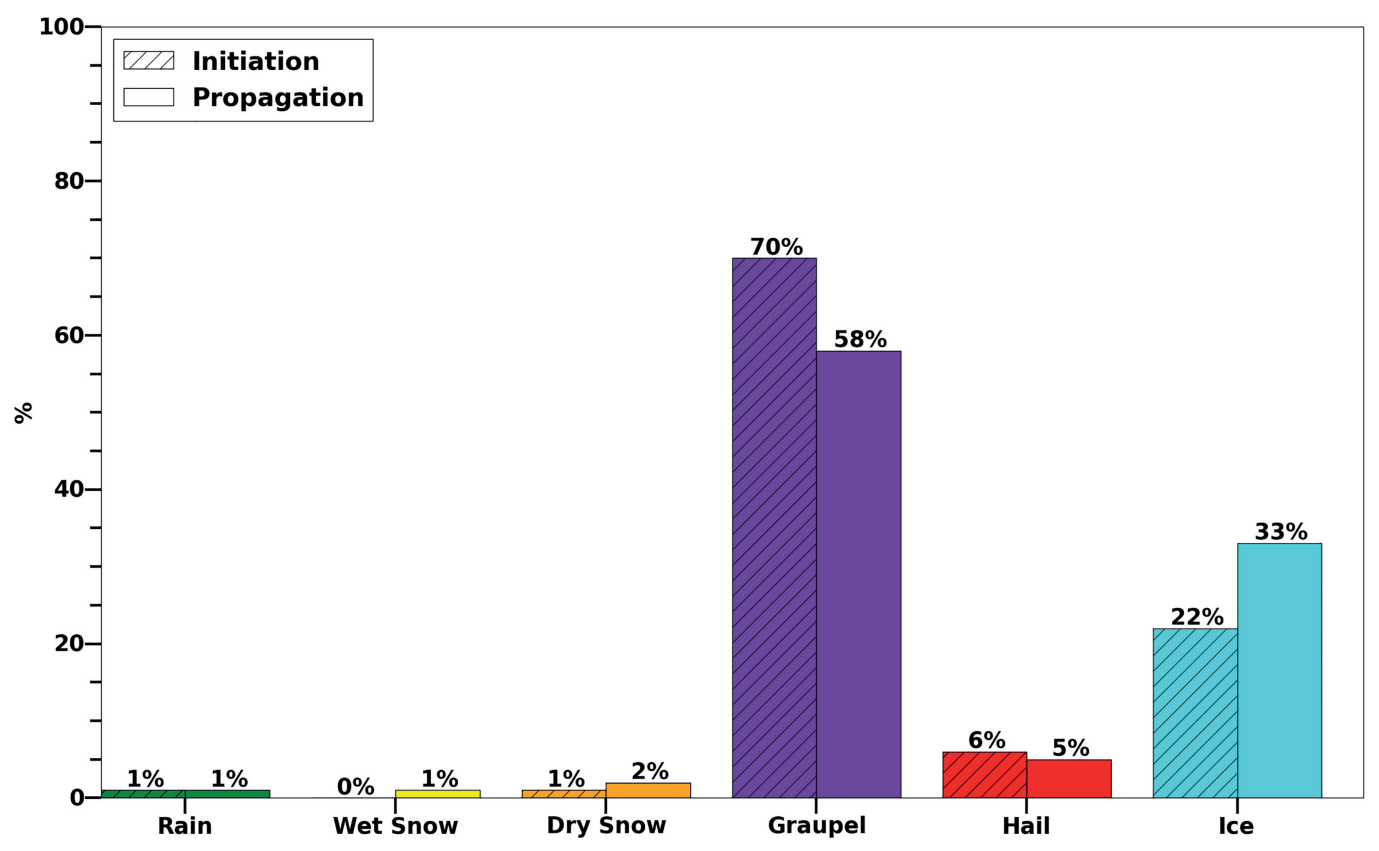

Figure 5. Percentages of hydrometeor species (rain, wet snow, dry snow, graupel, hail, ice) in relation to lightning initiation events (hatched) and propagation (filled) between 2330 and 0330 UTC on 23 and 24 September 2012.

given flash were associated with their collocated hydrometeor types deduced from the analysis of dual-polarimetric radar data. As explained previously the first source was considered separately to discriminate between lightning initiation events and propagation. Applying such a method to all flashes observed over the $4 \mathrm{~h}$ period of analysis allows determining the preferred microphysical medium for flash initiation and propagation. Results of this analysis are presented in Figure 5.

On average, lightning appears to be mostly triggered within the graupel $(70 \%)$ area, although a significant number of flashes were also initiated within ice $(22 \%)$ and hail $(6 \%)$ regions. Regarding propagation, it is seen that flashes also predominantly propagate through graupel (58\%), ice (33\%) and hail (5\%). A deeper analysis of these results (not shown) also indicates that a grid point classified as graupel has a probability of $75 \%$ of being affected by at least one flash. For hail and ice, these probabilities decrease to 40 and 7\%, respectively. The contribution of other microphysical species in lightning initiation occurrences and propagation was definitely not significant during the period of analysis. This result is consistent with previous studies of Bruning etal. (2007) and Lund et al. (2009) and confirms that the microphysical species involved in the general aspect of lightning occurrence within this convective event observed in southeastern France mimic those documented in the United States.

\subsection{Temporal evolution of lightning activity}

As discussed previously, the lightning activity was not evenly distributed during the $4 \mathrm{~h}$ period of analysis considered in this study. In order to understand the space and time variability of lightning during this global period, a detailed investigation of the kinematical and microphysical structure of the squall line was performed.

With this regard, Figure 6 shows wind, reflectivity and hydrometeor data at 0045 UTC, i.e. when the lightning activity was the most intense $\left(\sim 160\right.$ flashes $\cdot \mathrm{min}^{-1}$, Figure 3$)$. At this time, the system exhibited a $200 \mathrm{~km}$ wide convective line covering nearly the entire domain of analysis and was characterized by horizontal reflectivity values of up to $50 \mathrm{dBZ}$ (Figure 6(a)). The squall line was fed by the convergence resulting from the encounter of a deep and moist southeasterly flow of $\sim 20 \mathrm{~m} \cdot \mathrm{s}^{-1}$ originating over the Mediterranean Sea with a southwesterly-to-westerly flow at the leading edge of the system. In response to this low-level convergence, strong updraughts formed in the convective region
(Figure 6(b)) with maximum vertical velocity observed near $6 \mathrm{~km}$ AMSL. A west-east vertical cross-section through the most active part of the system shows reflectivity extending up to $35 \mathrm{dBZ}$ at the height of $8 \mathrm{~km}$ (Figure 6(c)), coinciding with a large proportion of graupel and a mix of ice and dry snow particles (Figure 6(d)). During this period VHF source densities were concentrated near $\sim 9 \mathrm{~km} \mathrm{AMSL}$, and around $5 \mathrm{~km}$ (Figure $6(\mathrm{~d})$ ). Lightning initiation events occurred throughout the troposphere but were restricted to the convective region of the system. The observed occurrence of VHF sources throughout the troposphere is however not realistic, but is likely due to errors in source altitude detected by the HyLMA, which increase with the range squared (Thomas et al., 2004).

The system reached its mature stage during period P2. The overall structure of the system during this period is shown in Figure 7 , which presents $3 \mathrm{D}$ wind and hydrometeor data inferred from the analysis of radar observations collected between 0130 and 0145 UTC. This period also corresponds to that of weakest lightning activity $\left(\sim 20\right.$ flashes $\cdot \mathrm{min}^{-1}$, Figure 3$)$. The vertical wind speed at $6 \mathrm{~km}$ has increased to reach up to $12 \mathrm{~m} \cdot \mathrm{s}^{-1}$ in the most active parts of the system (Figure $7(\mathrm{~b})$ ). Accordingly, the vertical extension of the MCS has also significantly increased as shown by the $35 \mathrm{dBZ}$ reflectivity pattern now extending up to a height of $10 \mathrm{~km}$ (Figure $7(\mathrm{c})$ ). Within the convective region, graupel was the primary hydrometeor species and could be observed within the $4-10 \mathrm{~km}$ layer (Figure $7(\mathrm{~d})$ ). Large amounts of ice and hail could also be observed at each extremity of the graupel layer, respectively. As mentioned previously, the lightning activity was less intense than during period P1. It was also distributed over a larger area and within the stratiform region. The strongest electrical activity was observed in the central part of the system $(x=120-140 \mathrm{~km}, y=60-140 \mathrm{~km})$, where more than $50 \%$ of VHF sources and a third of CGs occurred.

The bow echo began to break up at 0300 UTC, which more or less corresponds to the beginning of the third distinct period in terms of lightning activity. This period also marks the beginning of the transition between the mature and decaying phase of the system. At this time, the MCS was still exhibiting high reflectivity values at mid-level (Figure $8(\mathrm{a})$ ). The strongest vertical motions occurred within a particularly intense convective cell located at the southern tip of the system (Figure $8(\mathrm{~b})$ ), while significant subsiding motions could also be observed in the rear-to-front inflow at the rear of the bow-echo region. The southern cell was very intense and showed reflectivity values up 

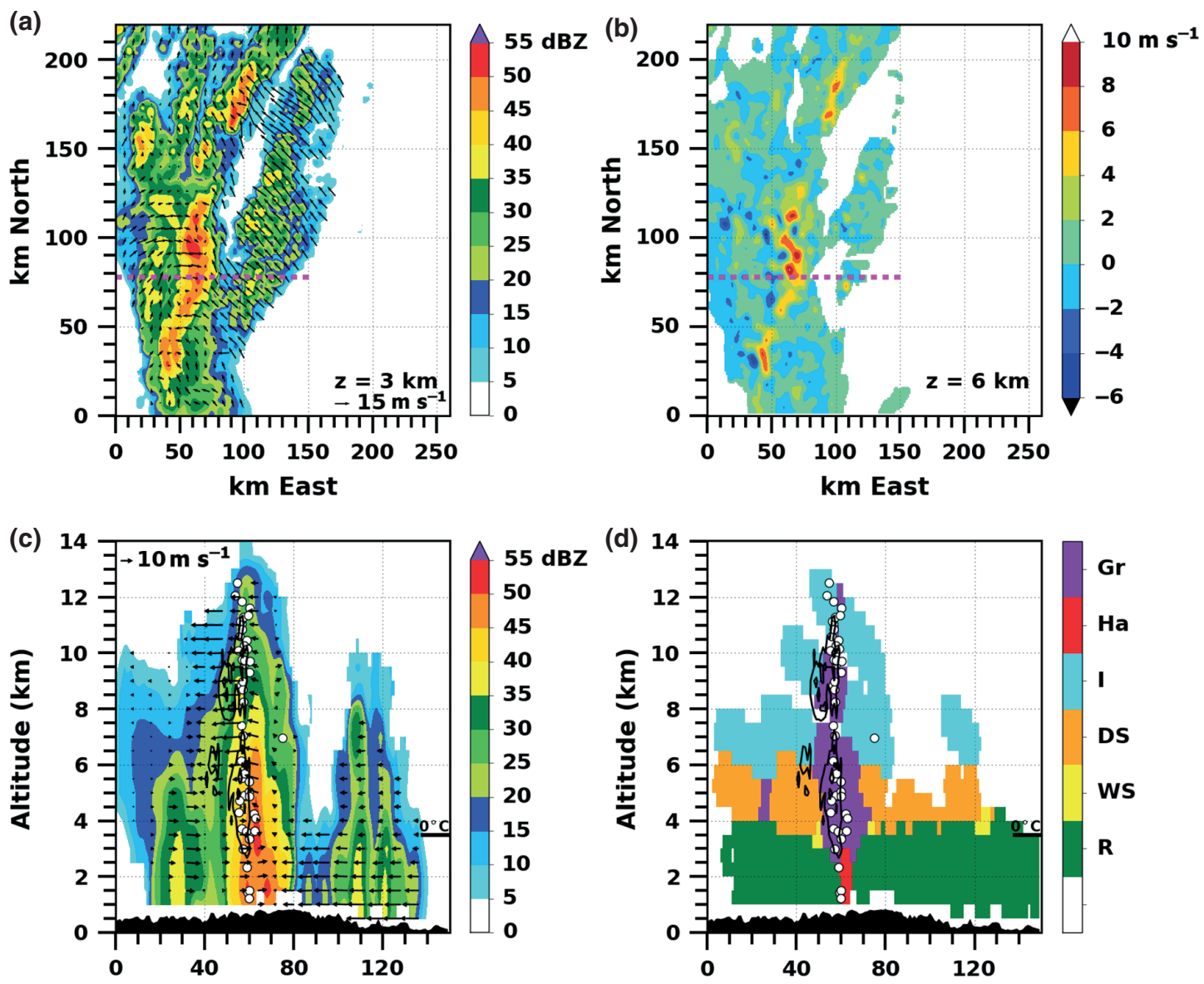

Figure 6. Wind, reflectivity and hydrometeor observations inferred from the analysis of ground-based radar data collected between 0030 and 0045 UTC on 24 September 2012. (a) Horizontal cross-section of wind and reflectivity at $3 \mathrm{~km}$ AMSL. (b) Horizontal cross-section of vertical velocity at $6 \mathrm{~km}$ AMSL. (c) Vertical cross-section of wind and reflectivity. (d) Vertical cross-section of hydrometeor composite (Gr: Graupel, Ha: Hail, I: Ice, DS: Dry Snow, WS: Wet Snow, R: Rain). The location of the cross-section is indicated by the pink dashed line in (a,b). Black contours in (c) and (d) shows VHF source density in steps of $5 \mathrm{~km}{ }^{2}$. White dots correspond to lightning flash initiation. The estimations of $0^{\circ} \mathrm{C}$ isotherm altitude, retrieved by the ARPEGE model over dual-polarimetric radars, are depicted in (c) and (d).

to $25 \mathrm{dBZ}$ at $12 \mathrm{~km}$ AMSL (Figure $8(\mathrm{c}))$. As previously noted, graupel was the dominant particle type within the convective area (Figure $8(\mathrm{~d})$ ). Hail was still present at lower levels but in significantly less quantities than previously. Within the rearto-front inflow the hydrometeor distribution is consistent with stratiform precipitation and shows a mix of snow, rain and ice. During this period, lightning flashes mostly occurred within the southern part of the bow-echo system, at the interface between upand downdraught regions $(x=178 \mathrm{~km}, y=110 \mathrm{~km})$. Lightning activity was concentrated at very high altitude within a layer comprised between 9 and $14 \mathrm{~km}$. The VHF source density was continuously distributed from 5 to $12 \mathrm{~km}$ AMSL within both graupel and ice particles, whereas a weak lower VHF density was also observed around $4 \mathrm{~km}$.

Relationships between cloud microphysics and 3D lightning activity during the three different periods are presented in Figure 9. As noticed previously, graupel and ice crystals constitute the main species for both lightning initiation events and propagation at all times. Hence between 55\% (P3) and 78\% (P1) of lightning were initiated in graupel regions and between $13 \%(\mathrm{P} 1)$ and $41 \%$ (P3) were triggered in ice areas. One can note that the distribution of lightning flashes during periods P1 and P2 was very similar despite much lower global lightning activity during P2 (Figure 3(b)). A major change occurred during P3 (Figure 9(c)) as the proportion of lightning initiation events within graupel decreased from more than $70 \%$ to $55 \%$ and dramatically increased in ice-identified regions ( $41 \%$ from $\sim 15 \%$ over the two previous periods). Lightning propagation shows the same behaviour with a marked preference for flashes to propagate through graupel $(51-64 \%)$ and ice $(31-37 \%)$ regions. Hail seems to play a more important role during P1 and P2 ( 7\%, Figure 9(a) and (b)) for both lightning initiation occurrences and propagation.
The specific role of this particular hydrometeor is investigated hereafter.

\section{Discussion}

This section aims at further investigating the possible sources of the lightning variations observed previously, with emphasis on the second and third periods of analysis.

\subsection{An unexpected low lightning activity}

As mentioned previously the total flash rates during the second period of analysis P2 was significantly weaker than during the first and third periods ( $>100$ flashes $\cdot \mathrm{min}^{-1}$ vs. $\sim 40$ flashes $\cdot \mathrm{min}^{-1}$, Figure 3(b)) despite the fact that all ingredients required to achieve high flash rates seemed to be present $\left(w>10 \mathrm{~m} \cdot \mathrm{s}^{-1}\right.$ and $Z_{\mathrm{H}}>45 \mathrm{dBZ}$ at $6 \mathrm{~km}$ high - Figure 7(a) and (b)).

During this period the lightning activity was also enhanced within the stratiform region (Figure $4(\mathrm{~d})$ ). The overall vertical distribution of the total VHF discharges during the two first periods (Figure $7(\mathrm{c})$ and (d)) is consistent with the previous studies of Carey etal. (2005) and Lang and Rutledge (2008) who also observed a bimodal pattern in the 3D distribution of lightning within the trailing stratiform region of a squall line and in a bow-echo system, respectively. The observed VHF density consists of two layers extending from 8 to $11 \mathrm{~km}$, and from $\sim 4$ to $7 \mathrm{~km} \mathrm{AMSL}$, respectively. Although the bimodal distribution of the total VHF discharges is quite common, a significant change in lightning partition can nevertheless be observed between the first and the second periods. Indeed during period P1 the mid-level lightning activity occurred mostly at 

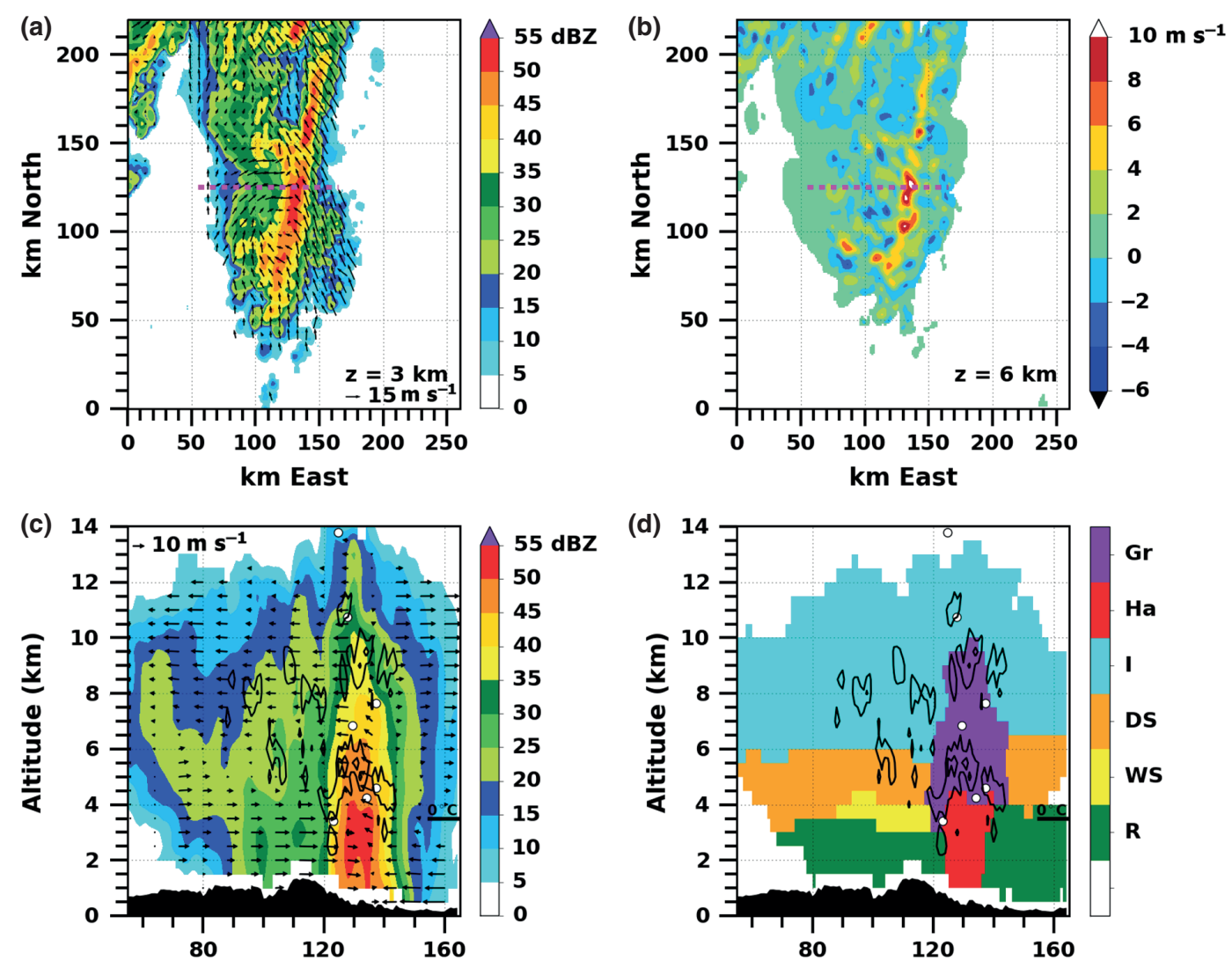

Figure 7. Same as Figure 6 but for 0130-0145 UTC.
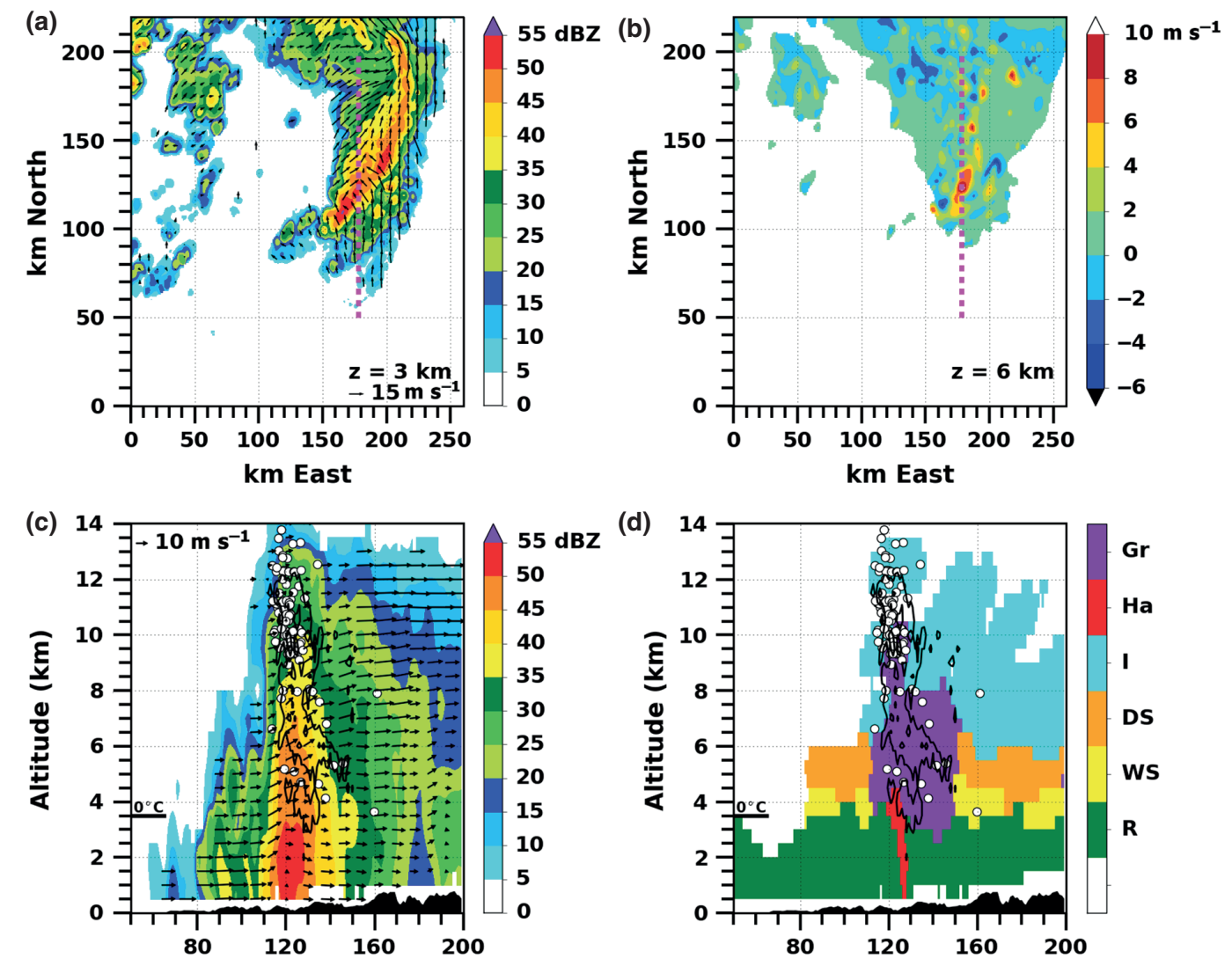

Figure 8. Same as Figure 6 but for $0245-0300$ UTC.

the rear of the convective area (Figure 6(c)), whereas it was mainly concentrated within the convective part of the system during P2 (Figure 7(c)). The lower lightning activity observed in the latter period might be due to a redistribution of charges within the MCS resulting from the detrainment of charged ice particles at the top of the convective area - this process would impact lightning initiation events through reducing the intensity of the electric field within the convective region. The distribution of the total lightning activity (Figure $7(\mathrm{~d})$ ), which indicates the presence of a lightning slanted pathway (Carey et al., 2005; Dotzek etal., 2005; Ely etal., 2008; Hodapp et al., 2008) between the convective upper charge layer $(x=135 \mathrm{~km})$ and the stratiform region at mid-level $(x=100 \mathrm{~km})$, seems to confirm this hypothesis. 
(a)
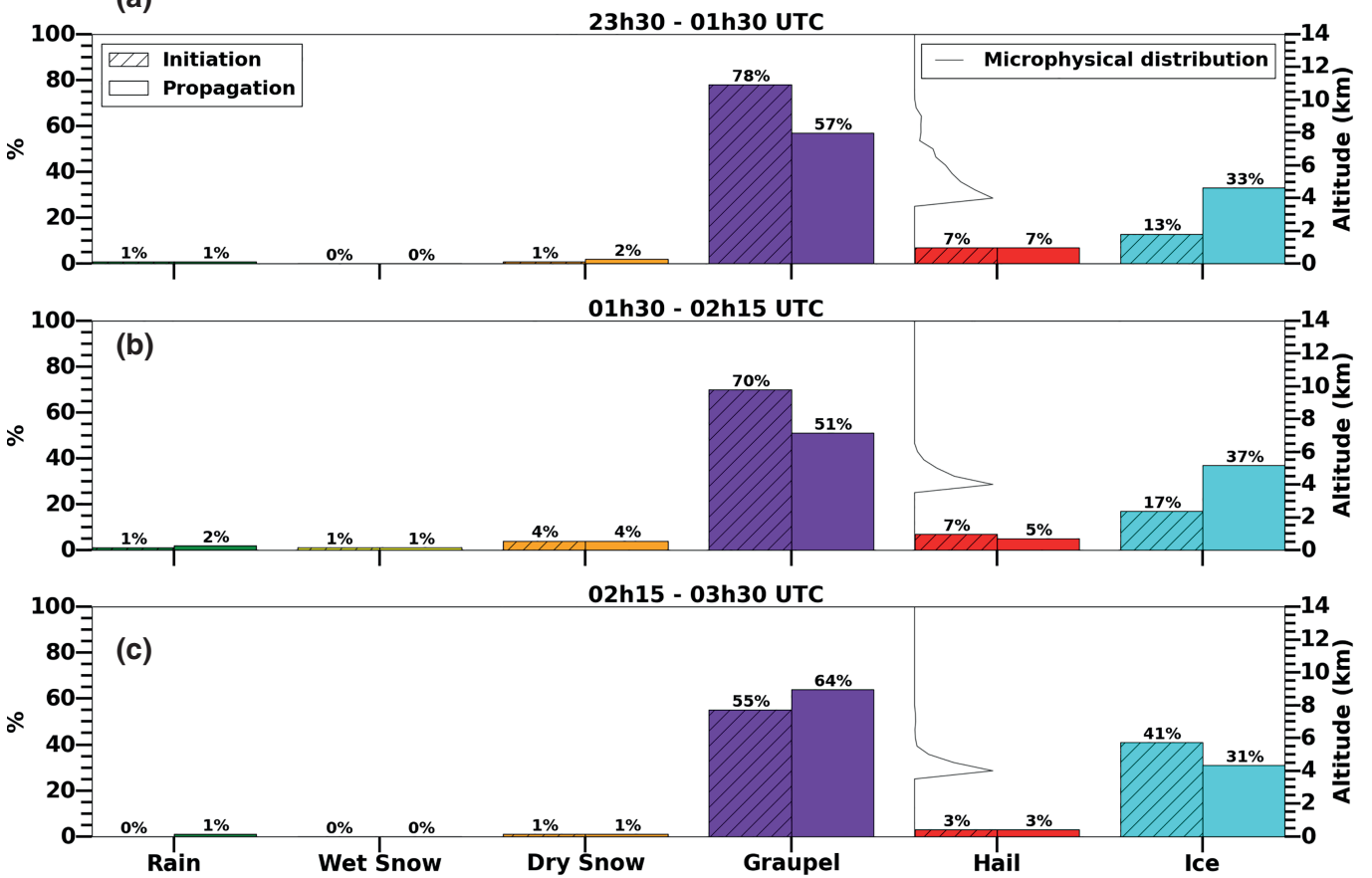

Figure 9. Same as Figure 5, but for the three different periods considered in the study. Thin black lines show the vertical distribution of hail concentration between 0 and $14 \mathrm{~km}$ AMSL (arbitrary units). (a) 2330-0130 UTC. (b) 0130-0215 UTC. (c) 0215-0330 UTC.

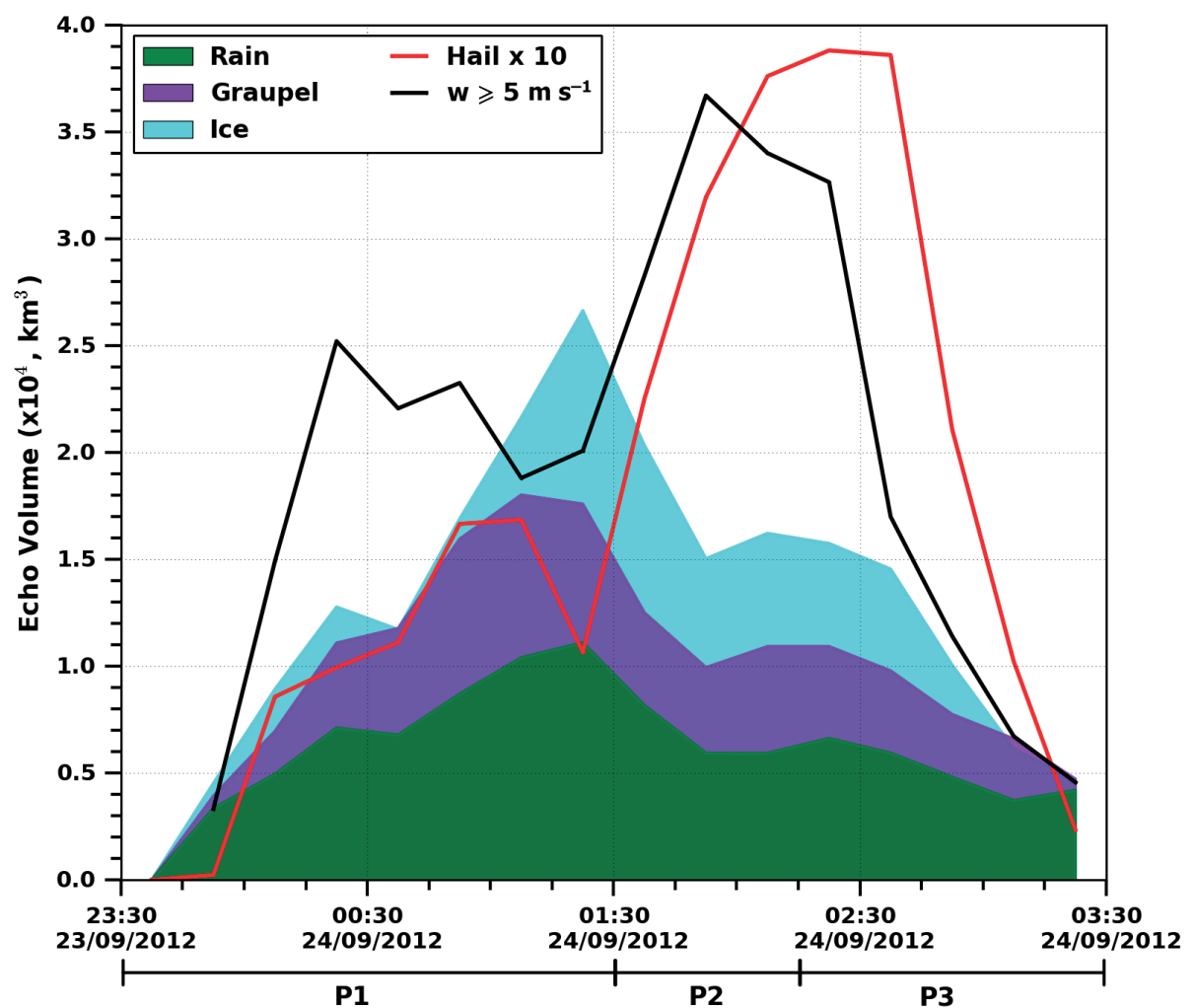

Figure 10. Time series of updraught $\left(w \geq 5 \mathrm{~m} \cdot \mathrm{s}^{-1}\right)$ and microphysical echo volumes deduced from multiple-Doppler analysis and 3D hydrometeor composites for rain, graupel, hail and ice.

Another possibility to account for this dramatic decrease of the lightning activity could be related to changes in the microphysical structure of the system. Figure 10 presents time series of rain, graupel, hail, ice and updraught $\left(w \geq 5 \mathrm{~m} \cdot \mathrm{s}^{-1}\right)$ volumes during the whole period of analysis. During the second period, one can notice that the total volume of hail increased by up to three times with respect to the previous one. This result is consistent with the observed reinforcement of upward convective motions and confirms that the system was in its mature stage during this period. With this regard, the significant decrease of electrical activity observed during period $\mathrm{P} 2$ is somewhat puzzling. The observed reduction in flash rate occurred together with both a dramatic increase of hail formation and an updraught surge starting around 0130 UTC (Figure 10). At this time hail was mostly distributed between 0 and $6 \mathrm{~km}$ AMSL, with maximum concentration near $3 \mathrm{~km}$ (thin black line, Figure 9). The occurrence of this maximum below the $0{ }^{\circ} \mathrm{C}$ isotherm is however not realistic and is likely related to a misbehaviour of the hydrometeor classification algorithm in this particular area, During this period one can nevertheless observe lightning holes within hail regions around $5 \mathrm{~km}$ AMSL (not shown). This suggests that hail may have had an impact on lightning activity through affecting the noninductive mechanism 

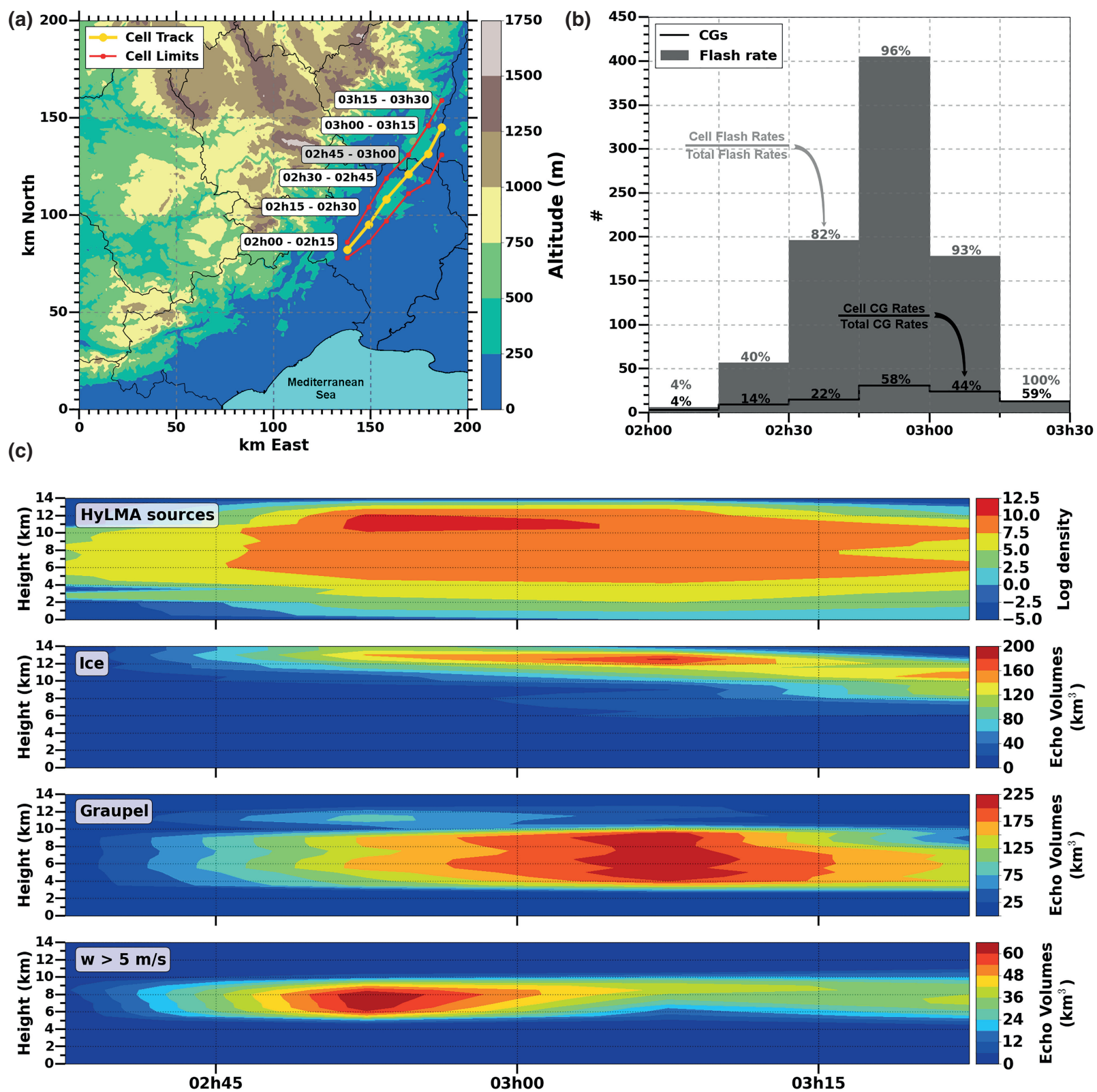

Figure 11. Lightning activity between 0200 and 0330 UTC within the most active cell of the system. (a) Convective cell trajectory (yellow) and horizontal extension (red). (b) Lightning flash (grey shaded) and CG rates (black curve) within the convective cell. Percentages correspond to the VHF (CGs) activity inside the convective cell compared to the total lightning (CGs) activity in the domain of analysis. (c) Time-height plots of VHF sources deduced from the HyLMA, along with vertical distribution of ice and graupel, and updraught $\left(w \geq 5 \mathrm{~m} \cdot \mathrm{s}^{-1}\right)$.

such as was observed by Saunders and Brooks (1992), Payne et al. (2010) and Emersic et al. (2011), among others.

\subsection{Potential impact of topography on lightning activity}

After a net decrease during P2, the total flash rate then rapidly increased near 0230 UTC to reach more than 100 flashes min $^{-1}$ (Figure 3(b)). The lightning activity, indicated by VHF discharges, mostly occurred in the convective areas and above the altitude of $6 \mathrm{~km}$ (Figure $4(\mathrm{c})$ ). The height of lightning initiation also steadily increased from 6 to $11.5 \mathrm{~km}$ (Figure $3(\mathrm{a})$ ) between 0220 and 0255 UTC, while the number of CG significantly decreased (Figure 3(b)). In-depth analysis of the spatial lightning distribution indicates that lightning activity was almost entirely concentrated within the deep convective cell located at the southern tip of the MCS (Figure 8). The trajectory of this cell and associated lightning activity between 0200 and 0330 UTC is shown in Figure $11(\mathrm{a}, \mathrm{b})$. The trajectory was estimated from the horizontal projection of VHF sources density by steps of $15 \mathrm{~min}$.

The cell progressed over flat terrain during the first 30 min before passing over a small-scale topographic obstacle $(x=160 \mathrm{~km}, y=110 \mathrm{~km})$ near 0230 UTC (Figure 11 (a)). At this time, both the total and CG lightning activity dramatically increased to ultimately account for $96 \%$ and $58 \%$ of the total lightning activity measured within the entire domain of analysis, respectively (Figure 11(b)). The lightning activity then sharply decreased once the cell has passed the obstacle. Time-height series of VHF sources, updraught $\left(w>5 \mathrm{~m} \cdot \mathrm{s}^{-1}\right)$, ice and graupel echo volumes within this specific cell are shown in Figure 11(c). The maximum of VHF source density was observed near $11 \mathrm{~km}$ AMSL between 0245 and 0300 UTC, which corresponds to the passage of the convective cell over the small topographic obstacle (Figure $11(\mathrm{a})-(\mathrm{c}))$. At this time, the vertical velocity also significantly increased. During this $15 \mathrm{~min}$ period, ice crystals were mostly concentrated near $13 \mathrm{~km}$ AMSL, whereas graupel was more evenly distributed between 4 and $9 \mathrm{~km}$ AMSL. One can however notice the presence of an anomaly of graupel density near $11 \mathrm{~km}$. The presence of graupel at such altitude is probably due to the sharp increase in vertical motion induced by the passage of the convective cell over the hill. These observations are consistent with numerical studies of Kirshbaum et al. (2007) and Letkewicz and Parker (2011), which showed that vertical velocities within a squall line crossing a small obstacle could be strongly affected by the impact of lee effect on low-level lifting. 
Several studies, based on radar observations and numerical simulations of convective systems developing in the Cévennes area, have also underlined this aspect (e.g. Miniscloux et al., 2001; Cosma et al., 2002; Anquetin et al., 2003).

During HyMeX IOP 6, the updraught surge resulting from the passage of the system over steep terrain acted to transport graupel particles within a region of high-density ice particles that likely disturbed the lightning activity. Later on, from 0300 to 0315 UTC, ice and graupel density continued to increase in response to the updraught surge but lightning activity began to slowly decrease. These observations tend to illustrate the potential impact of topography on lightning activity and suggest that even a small hill may significantly influence the distribution and intensity of lightning within convective areas. Note, however, that it is not possible to rule out the hypothesis that the cell was simply going through its life cycle as it went over the hill.

\section{Conclusions}

The lightning activity within a bow-echo system observed on 24 September 2012 during HyMeX IOP 6 was investigated from LMA, EUCLID and ground-based polarimetric radar data. According to LMA data, $97 \%$ and $93 \%$ of lightning initiation events and propagation occurred within the convective region of the system, respectively. These results are consistent with the previous study of Lang and Rutledge (2008) who investigated the distribution of lightning activity within a bow-echo system observed over the High Plains of the central United States. Using the synergy between LMA and polarimetric radar data, it was found that $70 \%$ (resp. 58\%) and 22\% (resp. 33\%) of lightning initiation (resp. propagation) occurred within graupel and ice regions, respectively. Hail also played an active role in terms of lightning activity despite its relatively small proportion with respect to other hydrometeor species. By contrast, others microphysical species such as rain, wet snow and dry snow had a very limited impact on lightning initiation events and propagation.

The temporal evolution of flash rates also revealed the existence of three distinct periods in terms of lightning activity. The first and third periods exhibited strong lightning activity within the convective region and almost no electrical activity within the stratiform area of the system. The second period showed much weaker flash rates in the convective area and significant electrical activity in the stratiform region of the squall line. The observed temporal variability of lightning activity was likely related to a redistribution of charge within the system, resulting from detrainment of ice particles at the top of the convective region, as well as to the influence of orography on convective updraughts.

The detailed analysis of the relationships between lightning and microphysics within an intense mesoscale precipitation system performed in this study is promising and attests to the benefit ensuing from the synergetic use of a 3D lightning imager and polarimetric radars. These results could be particularly useful to evaluate the performance of an explicit numerical lightning scheme such as, for example, the Cloud ELectrification and Lightning Scheme (CELLS: Barthe et al., 2012; Pinty et al., 2013), that was recently implemented in the Mesoscale Non-Hydrostatic research model (Meso-NH: Lafore etal., 1998). The planned permanent deployment of both an LMA and a new polarimetric radar on Corsica island (France) will allow further investigation of these issues in the near future.

\section{Acknowledgements}

The authors would like to especially thank Eric Defer, Stéphane Pedeboy, Paul Krehbiel, Ronald Thomas, William Rison, JeanPierre Pinty and Christophe Bovalo for fruitful discussions that helped refine ideas developed in this study. HyMeX SOP1 over France was supported by CNRS, Météo-France, CNES, IRSTEA, INRA through the large interdisciplinary international programme MISTRALS (Mediterranean Integrated STudies at Regional And Local Scales) dedicated to the understanding of the Mediterranean Basin environmental processes (http://www .mistrals-home.org) and by Grants ANR-11-BS56-0005 (IODAMED) and ANR-14-CE01-0014 (MUSIC).

\section{References}

Al-Sakka H, Boumahmoud A-A, Fradon B, Frasier SJ, Tabary P. 2013. A new fuzzy logic hydrometeor classification scheme applied to the French X-, C-, and S-Band polarimetric radars. J. Appl. Meteorol. Clim. 52: 2328-2344.

Anquetin S, Minsicloux F, Creutin J-D, Cosma S. 2003. Numerical simulation of orographic rainbands. J. Geophys. Res. 108: 8386, doi: 10.1029/2002JD001593.

Aran M, Amaro J, Arús J, Bech J, Figuerola F, Gayà M, Vilaclara E. 2009. Synoptic and mesoscale diagnosis of a tornado event in Castellcir, Catalonia, on 18th October 2006. Atmos. Res. 93: 147-160.

Barth MC, Cantrell CA, Brune WH, Rutledge SA, Crawford JH, Huntrieser H, Carey LD, MacGorman D, Weisman M, Pickering KE, Bruning E, Anderson B, Apel E, Biggerstaff T, Campos T, Campuzano-Jost P, Cohen R, Crounse J, Day DA, Diskin G, Flocke F, Fried A, Garland C, Heikes B, Honomichl S, Hornbrook R, Huey LG, Jimenez JL, Lang T, Lichtenstern M, Mikoviny T, Nault B, O'Sullivan D, Pan LL, Peischl J, Pollack I, Richter D, Riemer D, Ryerson T, Schlager H, St Clair J, Walega J, Weibring P, Weinheimer A, Wennberg P, Wisthaler A, Wooldridge PJ, Ziegler C. 2015. The Deep Convective Clouds and Chemistry (DC3) field campaign. Bull. Am. Meteorol. Soc. 96: 1281-1309, doi: 10.1175/BAMS-D13-00290.1.

Barthe C, Chong M, Pinty J-P, Bovalo C, Escobar J. 2012. CELLS v1.0: updated and parallelized version of an electrical scheme to simulate multiple electrified clouds and flashes over large domains. Geosci. Model Dev. 5: $167-184$.

Bousquet O, Chong M. 1998. A Multiple-Doppler Synthesis and Continuity Adjustment Technique (MUSCAT) to recover wind components from Doppler radar measurements. J. Atmos. Oceanic Technol. 15: 343-359.

Bousquet O, Tabary P. 2014. Development of a nationwide real-time 3-D wind and reflectivity radar composite in France. Q. J. R. Meteorol. Soc. 140: 611-625.

Bousquet O, Tabary P, Parent du Chatelet J. 2008. Operational multipleDoppler wind retrieval inferred from long-range radial velocity measurements. J. Appl. Meteorol. Clim. 47: 2929-2945.

Bousquet O, Berne A, Delanoë J, Dufournet Y, Gourley JJ, Van Baelen J, Augros C, Besson L, Boudevillain B, Caumont O, Defer E, Grazioli J, Jorgensen D, Kirstetter P-E, Ribaud J-F, Beck J, Delrieu G, Ducrocq V, Scipion DE, Schwarzenboeck A, Zwiebel J. 2015. Multifrequency radar observations collected in southern France during HyMeX-SOP1. Bull. Am. Meteorol. Soc. 96: 267-282, doi: 10.1175/BAMS-D-13-00076.1.

Bousquet O, Delanoe J, Bielli S. 2016. Evaluation of 3D wind observations inferred from the analysis of airborne and ground-based radars during HyMeX SOP-1. Q. J. R. Meteorol. Soc. , doi: 10.1002/qj.2710.

Bruning EC, Rust WD, Schuur TJ, MacGorman DR, Krehbiel PR, Rison W. 2007. Electrical and polarimetric radar observations of a multicell storm in TELEX. Mon. Weather Rev. 135: 2525-2544.

Carey LD, Murphy MJ, McCormick TL, Demetriades NWS. 2005. Lightning location relative to storm structure in a leading-line, trailing-stratiform mesoscale convective system. J. Geophys. Res. 110: D03105, doi: 10.1029/2003JD004371.

Carey LD, Bain AL, Retha M. 2015. 'Kinematic and microphysical control of lightning in multicell convection over Alabama during DC3.' In 5th International Conference on Lightning meteorology, 20-21 March 2014. Tucson, AZ.

Cosma S, Richard E, Miniscloux F. 2002. The role of small-scale orographic features in the spatial distribution of precipitation. Q. J. R. Meteorol. Soc. 128: $75-92$.

Defer E, Pinty J-P, Coquillat S, Martin J-M, Prieur S, Soula S, Richard E, Rison W, Krehbiel P, Thomas R, Rodeheffer D, Vergeiner C, Malaterre F, Pedeboy S, Schulz W, Farges T, Gallin L-J, Ortéga P, Ribaud J-F, Anderson G, Betz H-D, Meneux B, Kotroni V, Lagouvardos K, Roos S, Ducrocq V, Roussot O, Labatut L, Molinié G. 2015. An overview of the lightning and atmospheric electricity observations collected in southern France during the HYdrological cycle in Mediterranean EXperiment (HyMeX), Special Observation Period 1. Atmos. Meas. Tech. 8: 649-669.

Delrieu G, Nicol J, Yates E, Kirstetter P-E, Creutin J-D, Anquetin S, Obled C, Saulnier G-M, Ducrocq V, Gaume E, Payrastre O, Andrieu H, Ayral P-A, Bouvier C, Neppel L, Livet M, Lang M, Parent du-Châtelet J, Walpersdorf A, Wobrock W. 2005. The catastrophic flash-flood event of 8-9 September 2002 in the Gard region, France: A first case study for the CévennesVivarais Mediterranean hydrometeorological observatory. J. Hydrometeorol. 6: $34-52$.

Dotzek N, Rabin RM, Carey LD, MacGorman DR, McCormick TL, Demetriades NW, Murphy MJ, Holle RL. 2005. Lightning activity related to satellite and radar observations of a mesoscale convective system over Texas on 7-8 April 2002. Atmos. Res. 76: 127-166. 
Drobinski P, Ducrocq V, Alpert P, Anagnostou E, Béranger K, Borga M Braud I, Chanzy A, Davolio S, Delrieu G, Estournel C, Filali Boubrahmi N, Font J, Grubišic V, Gualdi S, Homar V, Ivancan-Picek B, Kottmeier C, Kotroni V, Lagouvardos K, Lionello P, Llasat MC, Ludwig W, Lutoff C, Mariotti A, Richard E, Romero R, Rotunno R, Roussot O, Ruin I, Somo S, Taupier-Letage I, Tintore J, Uijlenhoet R, Wernli H. 2013. HyMeX: A 10-year multidisciplinary program on the Mediterranean water cycle. Bull. Am. Meteorol. Soc. 95: 1063-1082.

Ducrocq V, Nuissier O, Ricard D, Lebeaupin C, Thouvenin T. 2008. A numerical study of three catastrophic precipitating events over southern France. II: Mesoscale triggering and stationarity factors. Q. J. R. Meteorol. Soc. 134: 131-145.

Ducrocq V, Braud I, Davolio S, Ferretti R, Flamant C, Jansa A, Kalthoff N Richard E, Taupier-Letage I, Ayral P-A, Belamari S, Berne A, Borga M, Boudevillain B, Bock O, Boichard J-L, Bouin M-N, Bousquet O, Bouvier C, Chiggiato J, Cimini D, Corsmeier U, Coppola L, Cocquerez P, Defe E, Delanoë J, Di Girolamo P, Doerenbecher A, Drobinski P, Dufournet Y, Fourrié N, Gourley JJ, Labatut L, Lambert D, Le Coz J, Marzano FS, Molinié G, Montani A, Nord G, Nuret M, Ramage K, Rison W, Roussot O, Said F, Schwarzenboeck A, Testor P, Van Baelen J, Vincendon B, Aran M, Tamayo J. 2014. HyMeX-SOP1: the field campaign dedicated to heavy precipitation and flash flooding in the northwestern Mediterranean. Bull. Am. Meteorol. Soc. 95: 1083-1100.

Ely BL, Orville RE, Carey LD, Hodapp CL. 2008. Evolution of the total lightning structure in a leading-line, trailing-stratiform mesoscale convective system over Houston, Texas. J. Geophys. Res. 113: D08114, doi: 10.1029/2007JD008445.

Emersic C, Heinselman PL, MacGorman DR, Bruning EC. 2011. Lightning activity in a hail-producing storm observed with phased-array radar. Mon. Weather Rev. 139: 1809-1825.

Figueras i Ventura J, Boumahmoud A-A, Fradon B, Dupuy P,, Tabary P. 2012. Long-term monitoring of French polarimetric radar data quality and evaluation of several polarimetric quantitative precipitation estimators in ideal conditions for operational implementation at C-band. Q. J. R. Meteorol. Soc. 138: 2212-2228.

Fujita TT. 1978. 'Manual of downburst identification for project NIMROD.' Satellite and Mesometeorology Research Paper 156, Department of Geophysical Sciences, University of Chicago, Chicago, IL.

Giangrande SE, Krause JM, Ryzhkov AV. 2008. Automatic designation of the melting layer with a polarimetric prototype of the WSR-88D radar. J. Appl. Meteorol. Clim. 47: 1354-1364.

Gourley JJ, Tabary P, Parent du Chatelet J. 2006. Data quality of the Meteo-France C-Band polarimetric radar. J. Atmos. Oceanic Technol. 23: $1340-1356$

Gourley JJ, Tabary P, Parent du Chatelet J. 2007. A fuzzy logic algorithm for the separation of precipitating from nonprecipitating echoes using polarimetric radar observations. J. Atmos. Oceanic Technol. 24: 1439-1451.

Hodapp CL, Carey LD, Orville RE. 2008. Evolution of radar reflectivity and total lightning characteristics of the 21 April 2006 mesoscale convective system over Texas. Atmos. Res. 89: 113-137.

Illingworth AJ, Blackman TM. 2002. The need to represent raindrop size spectra as normalized gamma distributions for the interpretation of polarization radar observations. J. Appl. Meteorol. 41: 286-297.

Kirshbaum DJ, Bryan GH, Rotunno R, Durran DR. 2007. The triggering of orographic rainbands by small-scale topography. J. Atmos. Sci. 64: 1530-1549.

Krehbiel PR, Thomas RJ, Rison W, Hamlin T, Harlin J, Davis M. 2000 GPS-based mapping system reveals lightning inside storms. Eos. Trans. Am Geophys. Union 81: 21-25.

Lafore J-P, Stein J, Asencio N, Bougeault P, Ducrocq V, Duron J, Fischer C, Héreil P, Mascart P, Masson V, Pinty JP, Redelsperger JL, Richard E, VilàGuerau de Arellano J. 1998. The Meso-NH atmospheric simulation system. Part I: Adiabatic formulation and control simulations. Ann. Geophys. 16: 90-109.

Lang TJ, Rutledge SA. 2008. Kinematic, microphysical, and electrica aspects of an asymmetric bow-echo mesoscale convective system observed during STEPS 2000. J. Geophys. Res. 113: D08213, doi: 10.1029/2006 JD007709.

Lang TJ, Miller LJ, Weisman M, Rutledge SA. 2004. The Severe Thunderstorm Electrification and Precipitation Study. Bull. Am. Meteorol. Soc. 85: $1107-1125$

Letkewicz CE, Parker MD. 2011. Impact of environmental variations on simulated squall lines interacting with terrain. Mon. Weather Rev. 139: 3163-3183.
Lund NR, MacGorman DR, Schuur TJ, Biggerstaff MI, Rust WD. 2009. Relationships between lightning location and polarimetric radar signatures in a small mesoscale convective system. Mon. Weather Rev. 137: $4151-4170$.

MacGorman DR, Rust WD. 1998. The Electrical Nature of Storms. Oxford University Press: New York, NY.

MacGorman DR, Rust WD, Schuur TJ, Biggerstaff MI, Straka JM, Ziegler CL, Mansell ER, Bruning EC, Kuhlman KM, Lund NR, Biermann NS. 2008. TELEX: the thunderstorm electrification and lightning experiment. Bull. Am. Meteorol. Soc. 89: 997-1013.

Makowski JA, MacGorman DR, Biggerstaff MI, Beasley WH. 2013. Total lightning characteristics relative to radar and satellite observations of Oklahoma mesoscale convective systems. Mon. Weather. Rev. 141: 1593-1611.

Marzano FS, Scaranari D, Celano M, Alberoni PP, Vulpiani G, Montopoli M. 2006. Hydrometeor classification from dual-polarized weather radar: extending fuzzy logic from S-band to C-band data. Adv. Geosci. 7: 109-114.

Mecikalski RM, Bain AL, Carey LD. 2015. Radar and lightning observations of deep moist convection across northern Alabama during DC3: 21 May 2012. Mon. Weather. Rev. 143: 2774-2794, doi: 10.1175/MWR-D-14-00250.1.

Meng ZY, Zhang YJ. 2012. On the squall lines preceding landfalling tropical cyclones in China. Mon. Weather Rev. 140: 445-470.

Miniscloux F, Creutin JD, Anquetin S. 2001. Geostatistical analysis of orographic rainbands. J. Appl. Meteorol. 40: 1835-1854.

Park HS, Ryzhkov AV, Zrnic D, Kim K-E. 2009. The hydrometeor classification algorithm for the polarimetric WSR-88D: description and application to an MCS. Weather and Forecasting 24: 730-748.

Payne CD, Schuur TJ, MacGorman DR, Biggerstaff MI, Kuhlman KM, Rust WD. 2010. Polarimetric and Electrical Characteristics of a Lightning Ring in a Supercell Storm. Mon. Wea. Rev. 138: 2405-2425, doi: 10.1175/2009 MWR3210.1.

Pinty J-P, Barthe C, Defer E, Richard E, Chong M. 2013. Explicit simulation of electrified clouds: from idealized to real case studies. Atmos. Res. 123: $82-92$.

Ribaud J-F, Bousquet O, Coquillat S, Al-Sakka H, Lambert D, Ducrocq V, Fontaine E. 2016. Evaluation and application of hydrometeor classification algorithm outputs inferred from multi-frequency dual-polarimetric radar observations collected during HyMeX. Q. J. R. Meteorol. Soc., doi: 10.1002/qj.2589.

Rison W, Thomas RJ, Krehbiel PR, Hamlin T, Harlin J. 1999. A GPS-based three-dimensional lightning mapping system: initial observations in central New Mexico. Geophys. Res. Lett. 26: 3573-3576.

Saunders CPR, Brooks IM. 1992. The effects of high liquid water content on thunderstorm charging. J. Geophys. Res. 97: 14671-14676, doi: 10.1029/ 92JD01186.

Saunders CPR, Keith WD, Mitzeva RP. 1991. The effect of liquid water on thunderstorm charging. J. Geophys. Res. 96: 11007-11017, doi: 10.1029/ 91JD00970.

Schulz W, Poelman D, Pedeboy S, Vergeiner C, Pichler H, Diendorfer G, Pack S. 2014. Performance Validation of the European Lightning Location System EUCLID. International Colloquium on Lightning and Power systems (CIGRÉ), Lyon, France.

Tabary P, Vulpiani G, Gourley JJ, Illingworth AJ, Thompson RJ, Bousquet O. 2009. Unusually high differential attenuation at C Band: results from a two-year analysis of the French Trappes polarimetric radar data. J. Appl. Meteorol. Clim. 48: 2037-2053.

Takahashi T. 1978. Riming electrification as a charge generation mechanism in thunderstorms. J. Atmos. Sci. 35: 1536-1548.

Thomas R, Krehbiel P, Rison W, Harlin J, Hamlin T, Campbell N. 2003. 'The LMA flash algorithm.' In 12th International Conference on Atmospheric Electricity, 9-13 June 2003. International Commission on Atmospheric Electricity: Versailles, France, pp. 655-656.

Thomas RJ, Krehbiel PR, Rison W, Hunyady SJ, Winn WP, Hamlin T, Harlin J. 2004. Accuracy of the lightning mapping array. J. Geophys. Res. 109: D14207, doi: 10.1029/2004JD004549.

Wiens KC, Rutledge SA, Tessendorf SA. 2005. The 29 June 2000 supercell observed during STEPS. Part II: Lightning and charge structure. J. Atmos. Sci. 62: 4151-4177.

Williams ER. 1989. The tripole structure of thunderstorms. J. Geophys. Res. 94: 13151-13167, doi: 10.1029/JD094iD11p13151. 